\title{
Research Progress on the Anti-Disproportionation of the ZrCo Alloy by Element Substitution
}

\author{
Mingde $\mathrm{Wu}^{1,2}{ }^{10}$, Jingchuan Wang ${ }^{2}$, Peilong $\mathrm{Li}^{2}$, Cun $\mathrm{Hu}^{2} \oplus$, Xiaofeng Tian ${ }^{1, *}$ \\ and Jiangfeng Song $2, * \mathbb{C}$ \\ 1 The College of Nuclear Technology and Automation Engineering, Chengdu University of Technology, \\ Chengdu 610065, China; wumingde901129@163.com \\ 2 Institute of Materials, China Academy of Engineering Physics, Jiangyou 621908, China; \\ wangjingchuan@caep.cn (J.W.); lipeilong2012@126.com (P.L.); hucun402@163.com (C.H.) \\ * Correspondence: x.tian@cdut.edu.cn (X.T.); iterchina@163.com (J.S.); Tel.: +86-138-8202-0277 (X.T.); \\ +86-139-9010-5175 (J.S.)
}

Received: 8 August 2020; Accepted: 3 September 2020; Published: 8 September 2020

\begin{abstract}
Hydrogen-induced disproportionation (HID) during the cycles of absorption and desorption leads to a serious decline in the storage capacity of the ZrCo alloy, which has been recognized as the biggest obstacle to its application. Therefore, the prerequisite of a $\mathrm{ZrCo}$ application is to solve its anti-disproportionation problem in the field of rapid hydrogen isotope storage. Beyond surface modification and nanoball milling, this work systematically reviews the method of element substitution, which can obviously improve the anti-disproportionation. From a micro angle, as hydrogen atoms that occupy the $8 \mathrm{e}$ site in the $\mathrm{ZrCoH}_{3}$ lattice are instable and are considered to be the driving force of disproportionation, researchers believe that element substitution by changing the occupation of hydrogen atoms at the 8e site can improve the anti-disproportionation of the alloy. At present, Ti/ $\mathrm{Nb}$ substitutions for the $\mathrm{Zr}$ terminal among substitute elements have an excellent anti-disproportionation performance. In this work, up-to-date research studies on anti-disproportionation and its disproportionation mechanism of the $\mathrm{ZrCo}$ alloy are introduced by combining experiments and simulations. Moreover, the optimization of the alloy based on the occupation mechanism of $8 \mathrm{e}$ sites is expected to improve the anti-disproportionation of the $\mathrm{ZrCo}$ alloy.
\end{abstract}

Keywords: ZrCo alloy; element substitution; anti-disproportionation; hydrogen storage performance; storage and delivery system

\section{Introduction}

Fusion energy has the advantages of huge energy, abundant fuel resources, and low radioactivity, which meets our expectations for future energy. The famous fusion reactor, the International Thermonuclear Experimental Reactor (ITER), was built to research effectiveness, in the sense of technological possibility, using a deuterium-tritium plasma fusion reaction [1-13]. Due to the scarcity and radioactivity of tritium, and the actual operation of the fusion reactor, deuterium and tritium fuel gas must be quickly supplied to the fuel filling system in a limited time according to the operation scene of the plasma $[14,15]$. This requires an efficient and safe storage and delivery system (SDS) to ensure the smooth operation of the fusion reactor while avoiding radioactive hazards and waste of resources, and the SDS is a crucial important part of the ITER fuel cycle [16-18].

Compared with the general methods of high-pressure gaseous hydrogen storage and low-temperature liquid hydrogen storage, hydrogen storage metallic alloys have shown the ability to provide an excellent combination of economics, efficiency, and safety [19]. Uranium is widely used in the field of hydrogen treatment owing to its favorable characteristics of hydrogen intake and release 
temperature and pressure, but disadvantages such as radioactivity and spontaneous combustion also limit its application [20-25]. The $\mathrm{ZrCo}$ alloy has the advantages of good ${ }^{3} \mathrm{He}$ trapping, no radioactivity, low absorption pressure at room temperature, moderate hydrogen desorption temperature, and a higher hydrogen absorption and desorption rate [26-33]. In particular, the ZrCo alloy can be held at a moderate temperature to maintain the equilibrium pressure of hydrogen of $100 \mathrm{kPa}$. Furthermore, it can avoid the damage of thermal radiation and effectively reduce the tritium permeation effect caused by high temperature $[2,16,34,35]$. As a result, the $\mathrm{ZrCo}$ alloy has been selected as one of the important alternative materials for hydrogen storage by ITER.

However, the hydrogen-induced disproportionation (HID) property seriously weakens its hydrogen storage property in the hydrogen absorption and desorption cycle, and it is still a great challenge that cannot be properly solved by far [36,37]. Up-to-date related research studies focusing on the anti-disproportionation of the $\mathrm{ZrCo}$ alloy by element substitution were reviewed in this study to tune its mechanism and improve the performance.

\section{Hydrogen Storage Characteristics of ZrCo}

Konishi and Nagasaki et al. [31,38,39] studied the ZrCo alloy and reported it as a hydrogen isotope/hydrogen storage alloy that can replace uranium. Then Shmayda et al. [2] further found that the thermodynamic hydrogen storage properties of the ZrCo alloy and uranium are very similar, but the $\mathrm{ZrCo}$ alloy does not have uranium's radioactivity and its price is reasonable. It was found that, compared to uranium, the $\mathrm{ZrCo}$ alloy has a lower hydrogen absorption plateau pressure at room temperature and an appropriate temperature under a higher desorption hydrogen plateau pressure. These two characteristics are of significance for the storage and delivery of hydrogen isotopes, because a high temperature during the process of hydrogen desorption and a high platform pressure during the process of hydrogen absorption increase the possibility of tritium permeation [40-42].

In addition, the $\mathrm{ZrCo}$ alloy exhibits a good isotope effect, which is beneficial for the separation of the hydrogen isotopes, and the isotope effect is greatly affected by the temperature. The kinetic property test indicates that the absorption rate for deuterium and tritium is slower than that of hydrogen. Moreover, the disproportionation reaction is faster with hydrogen than deuterium, which is well explained by a nucleation and nuclei growth model. However, the maximum extent of disproportionation remains unchanged with different isotopes [10,43,44].

Generally, five steps are required for the ZrCo alloy to absorb hydrogen molecules. The hydrogen adsorption process is as follows: (1) gaseous hydrogen molecules are physically adsorbed onto the metal surface, (2) gaseous hydrogen molecules dissociate into hydrogen atoms and hydrogen atoms are chemically absorbed onto the metal surface, (3) hydrogen atoms permeate into the metal lattice, (4) hydrogen atoms diffuse into the metal interior through the hydride layer, and (5) hydrogen atoms further form a hydride at the metal-hydride interface [45]. As shown in Equation (1) and Figure 1:

$$
2 \mathrm{ZrCo}+3 \mathrm{H}_{2} \leftrightarrow 2 \mathrm{ZrCoH}_{3}
$$

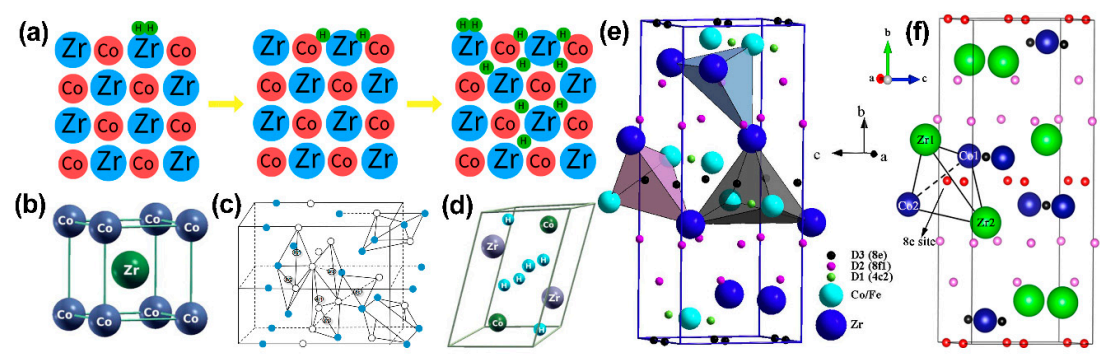

Figure 1. (a) Dissociation, adsorption, and permeation of hydrogen molecules; (b) crystal structure of $\mathrm{ZrCo}$ [46]; (c) the 6 types of tetrahedral sites and 2 types of octahedral sites of $\mathrm{ZrCoH}_{3}$ are illustrated [10]; (d) crystal structure of $\mathrm{ZrCoH}_{3}$ [46]; (e) crystal structure of $\mathrm{ZrCo}_{0.9} \mathrm{Fe}_{0.1} \mathrm{D}_{3}$ [47]; (f) structure of $\mathrm{ZrCoH}_{3}$ [48]. 
The space group of $\mathrm{ZrCo}$ is $\mathrm{Pm}-3 \mathrm{~m}$. Under ideal conditions, the maximum content of $\mathrm{H}$ in the $\mathrm{ZrCo}-\mathrm{H}_{2}$ system is that each $\mathrm{Zr}$ atom matches $3 \mathrm{H}$ atoms, and the space group of $\mathrm{ZrCoH}_{3}$ is $\mathrm{Cmcm}$.

The dehydrogenation process involves the opposite steps mentioned above. In fact, the hydrogen absorption and desorption rate of the $\mathrm{ZrCo}$ alloy is lower than that of uranium. Uranium can adsorb $90 \%$ of hydrogen in $200 \mathrm{~s}$, whereas the ZrCo alloy takes $620 \mathrm{~s}$ for the same process, and this is one of the reasons why it cannot be applied to the ITER [2]. Another reason is that in steps (4) and (5), when the temperature is higher than $573 \mathrm{~K}$, the disproportionation during de-/hydrogenation reactions between $\mathrm{ZrCo}$ and $\mathrm{H}_{2}$ occurs as represented by Equations (2) and (3) [49-52]. The higher the temperature and hydrogen pressure, the greater the rate and degree of disproportionation reaction can become. Hydrogen-induced disproportionation of the $\mathrm{ZrCo}$ alloy was initially reported by Shmayda [2]. The study of Konishi et al. showed that the ZrCo alloy disproportionates obviously when the temperature is higher than $400{ }^{\circ} \mathrm{C}$ and the hydrogen pressure is higher than the equilibrium hydrogen pressure, and the complete disproportionation only takes $5 \mathrm{~h}$ at $500{ }^{\circ} \mathrm{C}$ [53]. Hara et al. also showed that with the increase in temperature, disproportionation accelerates when the temperature is lower than $815 \mathrm{~K}$, and starts to slow down when it exceeds $815 \mathrm{~K}$. Furthermore, the disproportionation rate has a relationship with the initial hydrogen pressure of $3 / 2$ power [44], as follows:

$$
\begin{gathered}
2 \mathrm{ZrCoH}_{3} \rightarrow \mathrm{ZrH}_{2}+\mathrm{ZrCo}_{2}+2 \mathrm{H}_{2} \\
2 \mathrm{ZrCo}+\mathrm{H}_{2} \rightarrow \mathrm{ZrH}_{2}+\mathrm{ZrCo}_{2}
\end{gathered}
$$

The disproportionation product $\mathrm{ZrCo}_{2}$ loses its hydrogen absorption capacity; meanwhile, the other product, $\mathrm{ZrH}_{2}$, is more stable than $\mathrm{ZrCoH}_{3}$ and needs a temperature much higher than $500{ }^{\circ} \mathrm{C}$ to completely release hydrogen atoms [54]. There is no doubt that the disproportionation reaction breaks the reversible process of the hydrogen absorption and desorption cycle and weakens the hydrogen storage capacity of the alloy. Up-to-date research work has studied the occupation mechanism of the $\mathrm{H}$ atom to improve anti-disproportionation. In fact, the crystal structure (orthorhombic system) of $\mathrm{ZrCoH}_{3}$ is similar to that of $\mathrm{ZrNiH}_{3}$ [55-57]. The tetrahedral sites in $\mathrm{ZrCoH}_{3}$ lattices can be divided into six types according to the difference of the nearest neighbor coordination atoms of the hydrogen atoms, i.e., $4 \mathrm{c}_{1}, 4 \mathrm{c}_{2}, 8 \mathrm{f}_{1}, 8 \mathrm{~g}_{1}, 8 \mathrm{f}_{2}$, and $8 \mathrm{e}$. Because the sizes of $8 \mathrm{f}_{2}$ and $8 \mathrm{e}$ sites are too small, they are called unstable occupation sites of hydrogen atoms. For example, the distances of $8 \mathrm{f}_{2}-8 \mathrm{f}_{2}$ sites, $8 \mathrm{f}_{2}-8 \mathrm{e}$ sites, and adjacent $8 \mathrm{e}-8 \mathrm{e}$ sites are $1.1 \AA, 1.3 \AA$, and $1.8 \AA$, respectively. Thus, hydrogen atoms can only occupy part of them [16]. Ideally, $\mathrm{H}$ atoms only occupy sites of $4 \mathrm{c}_{2}$ and $8 \mathrm{f}_{1}$ in the crystal structure, but this is difficult to achieve in practice. Jat et al. [58] investigated deuterium atoms' space occupation in the $\mathrm{ZrCoD}_{3}$ lattice through neutron diffraction, and confirmed that deuterium atoms did occupy mainly $8 \mathrm{f}_{1}, 4 \mathrm{c}_{2}$, and $8 \mathrm{e}$ sites, with proportions of $66.9 \%, 29.3 \%$, and $3.8 \%$, respectively. The structure of $\mathrm{ZrCoH}_{3}$ used in calculations is shown in Figure 1f $[48,58]$. Many studies have shown that the $\mathrm{H}$ atoms entering the 8e site in the HID process are the driving force for the disproportionation of the $\mathrm{ZrCo}$ alloy $[10,48,58-60]$.

In order to solve the disproportionation problem of the $\mathrm{ZrCo}$ alloy and improve its dynamic properties, a large number of attempts have been carried out in recent years. The main aspects are as follows: (1) the study of element substitution of the ZrCo alloy and (2) the study of the disproportionation mechanism. In this work, the research progress on $\mathrm{ZrCo}$-based alloys in recent years is reviewed, with an emphasis on the effect of element substitution on anti-disproportionation properties and its deep-seated mechanism.

\section{Effects of Element Substitution on Anti-Disproportionation}

The $\mathrm{ZrCo}$ alloy is an excellent hydrogen storage material with low equilibrium pressure at room temperature, high hydrogen absorption content $(1.96 \mathrm{wt} \%)$, strong safety, and better hydrogen fixation capacity than metal uranium. Its molecular weight is $150.15 \mathrm{~g} / \mathrm{mol}$, the melting point is $\sim 1380{ }^{\circ} \mathrm{C}$ and the crystal structure is CsCl-type cubic (bcc). The lattice constant and the cell volume are $3.196 \AA$ 
and $32.65 \AA^{3}$, respectively [42]. It was found that the disproportionation of the ZrCo alloy occurs obviously when the hydrogen desorption temperature is above $350{ }^{\circ} \mathrm{C}$. Generally, with a high hydrogen pressure, the disproportionation rate increases with an increase in temperature. In actual experiments, the desorption temperature required for $\mathrm{ZrCo}$ hydride to release hydrogen into a $100 \mathrm{KPa}$ hydrogen pressure atmosphere is $400^{\circ} \mathrm{C}[2,16]$. There is no doubt that, under the condition of satisfying our higher hydrogen pressure transfer rate in SDS, this temperature will induce an obvious disproportionation effect. Although the disproportionation of $\mathrm{ZrCo}$ can be regenerated under an ultra-high temperature and vacuum condition, it is not practical in application.

Therefore, in order to restrain the occurrence of disproportionation and explore its mechanism, researchers tried the method of element substitution, with the precondition that the hydrogen absorption and desorption ability of the alloy cannot be destroyed. In fact, researchers have tried many substitute elements ( $\mathrm{Cu}, \mathrm{Cr}, \mathrm{Mn}, \mathrm{Al}, \mathrm{Fe}, \mathrm{Ni}, \mathrm{Ti}, \mathrm{Hf}, \mathrm{Sc}$ ) [61-67]. For example, $\mathrm{Hf}$ and $\mathrm{Zr}$ are in the same main family, and $\mathrm{HfCo}$ and $\mathrm{ZrCo}$ have the same structure of $\mathrm{CsCl}$. Hf-doped $\mathrm{ZrCoH}_{3}$ has a much better ability of anti-disproportionation than $\mathrm{ZrCo}$. However, a $\mathrm{Zr}_{0.8} \mathrm{Ti}_{0.2} \mathrm{Co}$ bed had a better cyclic hydrogen delivery property than that of both a $\mathrm{ZrCo}$ bed and a $\mathrm{Zr}_{0.8} \mathrm{Hf}_{0.2} \mathrm{Co}$ bed [18,62]. From the perspective of anti-disproportionation, this paper selected four representative substitute elements. ZrCo is an AB-type alloy, and $\mathrm{Ti}$ and $\mathrm{Nb}$ are A-terminal substitute elements, while $\mathrm{Ni}$ and $\mathrm{Fe}$ are B-terminal substitute elements. These substitute elements have similar electronic structures to $\mathrm{Zr}$ or $\mathrm{Co}$, and it is beneficial to form a single solid-solution phase, thus effectively avoiding the emergence of a multi-hydrogen pressure platform. At present, the method of element substitution for the $\mathrm{ZrCo}$ alloy is generally arc melting or magnetic levitation melting in vacuum, but when arc melting is used to replace Co with $\mathrm{Ni}$ or $\mathrm{Fe}$, a small amount of the $\mathrm{ZrCo}_{2}$ phase is produced in addition to the main phase $[16,47,68]$.

\subsection{Replacing $\mathrm{Zr}$ with $\mathrm{Nb}$ and $\mathrm{Ti}$}

$\mathrm{Nb}$ was used to substitute $\mathrm{Zr}$ in $\mathrm{ZrCoH}_{3}$ by the magnetic induction suspension melting method; the effects of $\mathrm{Nb}$ substitution on the microstructure and initial activation dehydrogenation thermodynamics are shown in Figure 2a,b. From the perspective of anti-disproportionation, the optimal solution is obtained when the amount of $\mathrm{Nb}$ in the $\mathrm{Zr}_{1-\mathrm{x}} \mathrm{Nb}_{\mathrm{x}} \mathrm{Co}(\mathrm{x}=0.1,0.15,0.2)$ is $\mathrm{X}=0.20$. The atomic radius of $\mathrm{Nb}$ is $1.43 \AA$, which is smaller than that of $\operatorname{Zr}(1.62 \AA)$. It can be seen from Table 1 that the lattice parameters and cell volume of the $\mathrm{ZrCo}$ phase decrease as the $\mathrm{Nb}$ content increases. The initial activation period decreases from $87.79 \mathrm{~h}$ for $\mathrm{ZrCo}$ to $8.08 \mathrm{~h}$ for $\mathrm{Zr}_{0.8} \mathrm{Nb}_{0.2} \mathrm{Co}$. The pressure of the desorption platform increases significantly from 0.197 bar $(x=0)$ to 0.85 bar $(x=0.2)$ at $350^{\circ} \mathrm{C}$. The experimental results, after 50 hydrogen absorption and desorption cycles at $350{ }^{\circ} \mathrm{C}$, are shown in Figure 2c. The hydrogen storage capacity retention rate of the $\mathrm{Zr}_{0.8} \mathrm{Nb}_{0.2} \mathrm{Co}$ alloy is $68.5 \%$, and it is much higher than that of the $\mathrm{ZrCo}$ alloy. From the point of view of thermodynamics, it can also be seen that the disproportionation energy of the new alloy increases from $147.8 \mathrm{~kJ} / \mathrm{mol}$ for $\mathrm{ZrCo}$ to $182.1 \mathrm{~kJ} / \mathrm{mol}$ for $\mathrm{Zr}_{0.85} \mathrm{Nb}_{0.15} \mathrm{Co}$ [69].

$\mathrm{Ti}$ is another substitute element for $\mathrm{Zr}$ to efficiently improve the hydrogen storage properties of the $\mathrm{ZrCo}$ alloy; the effects of Ti substitution on the microstructure and temperature-programmed hydrogen delivery curves are shown in Figure $2 d$,e. When the Ti content of $Z_{1-x} \operatorname{Ti}_{x} \operatorname{Co}(x=0.1,0.2$, $0.3)$ is $x=0.2$, the hydrogen desorption platform pressure can reach 1 bar at 350 degrees, and the temperature is much lower than the equilibrium temperature of the $\mathrm{ZrCo}$ alloy at a platform pressure of 1 bar $[16,18,70,71]$. As shown in Figure 2f, after seven hydrogen absorption and desorption cycles at $450{ }^{\circ} \mathrm{C}$, the hydrogen delivery amount of $\mathrm{Zr}_{0.8} \mathrm{Ti}_{0.2} \mathrm{Co}$ decreases from $17.18 \mathrm{~mol}$ to $14.34 \mathrm{~mol}$. In the study of its principle, it was found that Ti substitution reduces the hydrogen occupation of the $8 \mathrm{e}$ site and increases the corresponding $\mathrm{Zr}-\mathrm{H}$ distance [48]. The lattice parameters and cell volume also decrease as the Ti content increases, as shown in Table 1 [9,72-74]. 
(a)

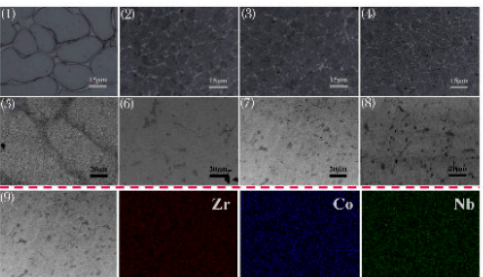

(d)

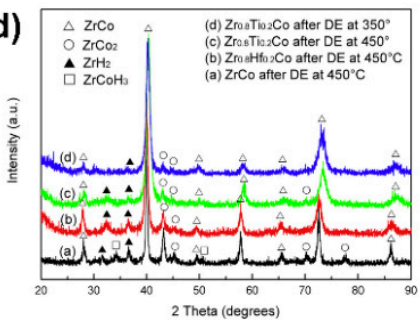

(b)

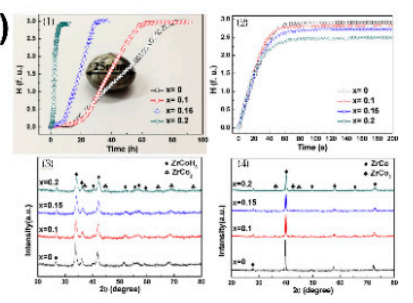

(e)

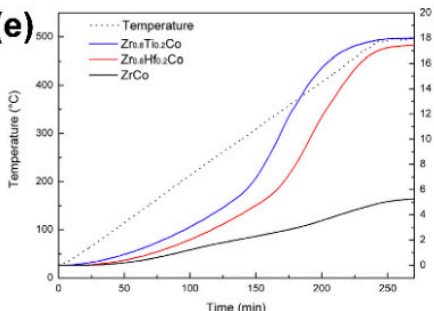

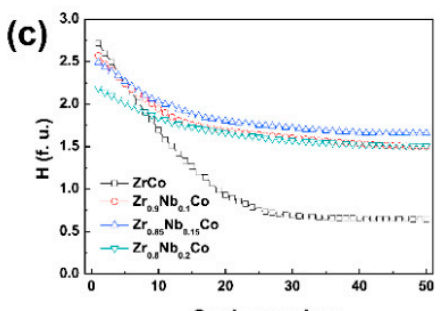

Cycle number

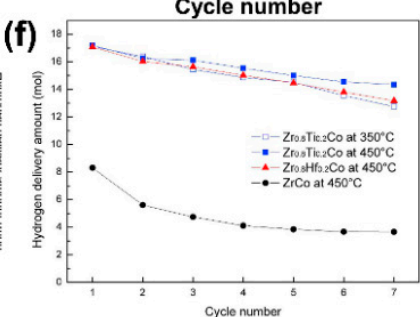

Figure 2. (a) Metallographic (1-4) and Back-scattered electron imaging (BSE) (5-8) micrographs of $\mathrm{Zr}_{1-\mathrm{x}} \mathrm{Nb}_{\mathrm{x}}$ Co alloys: (1), (5) $\mathrm{x}=0$; (2), (6) $\mathrm{x}=0.1 ;$ (3), (7) $\mathrm{x}=0.15$; (4), (8) $\mathrm{x}=0.2$. Energy dispersive $\mathrm{X}$-ray spectrometer (EDS) mapping micrographs (9) of the $\mathrm{Zr}_{0.85} \mathrm{Nb}_{0.15} \mathrm{Co}$ alloy; (b) ingot morphology and initial activation curves of $\mathrm{Zr}_{1-x} \mathrm{Nb}_{x}$ Co samples (1) and hydriding kinetics curves of activated $\mathrm{Zr}_{1-\mathrm{x}} \mathrm{Nb}_{\mathrm{x}} \mathrm{Co}$ samples (2). X-ray diffraction (XRD) patterns of $\mathrm{Zr}_{1-\mathrm{x}} \mathrm{Nb}_{\mathrm{x}} \mathrm{Co}-\mathrm{H}$ hydride samples after activation (3) and after dehydrogenation (4); (c) comparison of the cyclic hydrogen desorption capacity of $\mathrm{Zr}_{1-\mathrm{x}} \mathrm{Nb}_{\mathrm{x}} \mathrm{Co}-\mathrm{H}$ ( $\left.\mathrm{x}=0-0.2\right)$ at $350{ }^{\circ} \mathrm{C}$ [69]; (d) XRD patterns of the samples loaded in the various beds after hydrogen delivery for the seventh cycle; (e) temperature-programmed hydrogen delivery curves of the $\mathrm{ZrCo}$ bed, $\mathrm{Zr}_{0.8} \mathrm{Hf}_{0.2} \mathrm{Co}$ bed, and $\mathrm{Zr}_{0.8} \mathrm{Ti}_{0.2} \mathrm{Co}$ bed from room temperature to $500{ }^{\circ} \mathrm{C}$ at a $2{ }^{\circ} \mathrm{C}$ /min heating rate; (f) comparison of hydrogen delivery amounts of the $\mathrm{ZrCo}$ bed, $\mathrm{Zr}_{0.8} \mathrm{Ti}_{0.2} \mathrm{Co}$ bed, and $\mathrm{Zr}_{0.8} \mathrm{Hf}_{0.2} \mathrm{Co}$ bed for seven cycles at $350{ }^{\circ} \mathrm{C}$ and $450{ }^{\circ} \mathrm{C}$ [18].

Table 1. Lattice parameters and cell volumes of ZrCo-based alloys measured by XRD.

\begin{tabular}{|c|c|c|c|}
\hline Alloy & $\begin{array}{l}\text { Main Constituent Phase Lattice } \\
\text { Parameters (ZrCo phase) (̊̊) }\end{array}$ & Cell Volume (̊̊3) & Reference \\
\hline $\mathrm{ZrCo}$ & $3.1957 \pm 0.0001$ & $32.637 \pm 0.002$ & \multirow{4}{*}{ [68] } \\
\hline $\mathrm{ZrCo}_{0.9} \mathrm{Ni}_{0.1}$ & $3.1971 \pm 0.0042$ & $32.678 \pm 0.074$ & \\
\hline $\mathrm{ZrCo}_{0.8} \mathrm{Ni}_{0.2}$ & $3.1982 \pm 0.0041$ & $32.713 \pm 0.072$ & \\
\hline $\mathrm{ZrCo}_{0.7} \mathrm{Ni}_{0.3}$ & $3.1988 \pm 0.0020$ & $32.731 \pm 0.0035$ & \\
\hline $\mathrm{Zr}_{0.9} \mathrm{Ti}_{0.1} \mathrm{Co}$ & $3.1788 \pm 0.0001$ & $32.120 \pm 0.002$ & \multirow{3}{*}{ [9] } \\
\hline $\mathrm{Zr}_{0.8} \mathrm{Ti}_{0.2} \mathrm{Co}$ & $3.1591 \pm 0.0001$ & $31.528 \pm 0.002$ & \\
\hline $\mathrm{Zr}_{0.7} \mathrm{Ti}_{0.3} \mathrm{Co}$ & $3.1404 \pm 0.0001$ & $30.972 \pm 0.002$ & \\
\hline $\mathrm{Zr}_{0.9} \mathrm{Nb}_{0.1} \mathrm{Co}$ & 3.1898 & 32.49 & \multirow{3}{*}{ [69] } \\
\hline $\mathrm{Zr}_{0.85} \mathrm{Nb}_{0.15} \mathrm{Co}$ & 3.1836 & 32.34 & \\
\hline $\mathrm{Zr}_{0.8} \mathrm{Nb}_{0.2} \mathrm{Co}$ & 3.1773 & 32.2 & \\
\hline $\mathrm{Zr}_{0.8} \mathrm{Ti}_{0.2} \mathrm{Co}_{0.9} \mathrm{Ni}_{0.1}$ & 3.163 & 31.645 & \multirow{6}{*}{ [75] } \\
\hline $\mathrm{Zr}_{0.8} \mathrm{Ti}_{0.2} \mathrm{Co}_{0.8} \mathrm{Ni}_{0.2}$ & 3.161 & 31.581 & \\
\hline $\mathrm{Zr}_{0.8} \mathrm{Ti}_{0.2} \mathrm{Co}_{0.7} \mathrm{Ni}_{0.3}$ & 3.159 & 31.524 & \\
\hline $\mathrm{Zr}_{0.8} \mathrm{Ti}_{0.2} \mathrm{Co}_{0.9} \mathrm{Fe}_{0.1}$ & 3.1652 & 31.7105 & \\
\hline $\mathrm{Zr}_{0.8} \mathrm{Ti}_{0.2} \mathrm{Co}_{0.8} \mathrm{Fe}_{0.2}$ & 3.1655 & 31.7195 & \\
\hline $\mathrm{Zr}_{0.8} \mathrm{Ti}_{0.2} \mathrm{Co}_{0.7} \mathrm{Fe}_{0.3}$ & 3.1707 & 31.8761 & \\
\hline $\mathrm{ZrCo}_{0.9} \mathrm{Fe}_{0.1}$ & 3.1959 & 32.642 & [47] \\
\hline
\end{tabular}




\subsection{Replacing Co with $\mathrm{Ni}$ and Fe}

$\mathrm{Ni}$ was used to replace $\mathrm{Co}$ in $\mathrm{ZrCoH}_{3}$; the effects of $\mathrm{Ni}$ substitution for $\mathrm{Co}$ on the microstructure and hydrogen desorption pressure-composition isotherms are shown in Figure 3a,d. In the Ni-doped alloy $\mathrm{ZrCo}_{1-\mathrm{x}} \mathrm{Ni}_{\mathrm{x}}(\mathrm{x}=0.1,0.2,0.3), \mathrm{x}=0.3$ is the optimal solution. When the temperature is $583 \mathrm{~K}$, after 50 hydrogen absorption-desorption cycles, the ultimate hydrogen storage capacity is shown in Figure 3b: $\mathrm{ZrCo}_{0.7} \mathrm{Ni}_{0.3}>\mathrm{ZrCo}_{0.8} \mathrm{Ni}_{0.2}>\mathrm{ZrCo}>\mathrm{ZrCo}_{0.9} \mathrm{Ni}_{0.1}$. The XRD test shows that the lattice parameters and cell volume increase as the Ni content increased, as presented in Table $1[69,76]$. As the $\mathrm{Ni}$ content increases, the hydrogen atom occupancy of the $8 \mathrm{e}$ site decreases from $\sim 3.8 \%$ for $\mathrm{ZrCoD}_{3}$ to $\sim 2.5 \%$ for $\mathrm{ZrCo}_{0.7} \mathrm{Ni}_{0.3} \mathrm{D}_{3}$, and the $\mathrm{Zr}$-D distance of $\mathrm{ZrCoD}_{3}$ increases from $1.937 \AA$ to $2.022 \AA$ $\left(\mathrm{ZrCo}_{0.7} \mathrm{Ni}_{0.3} \mathrm{D}_{3}\right)[58]$.

(a)

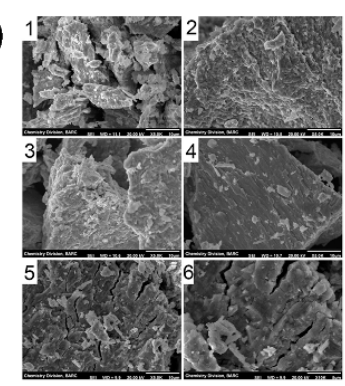

(b)

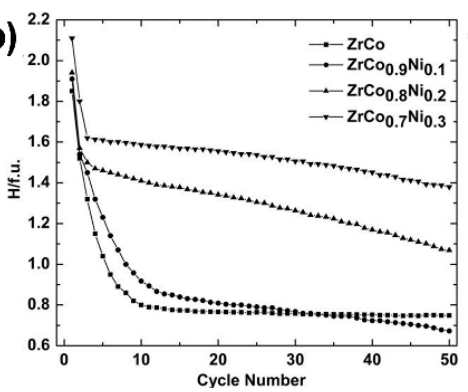

(e)

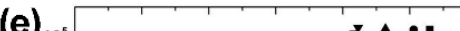

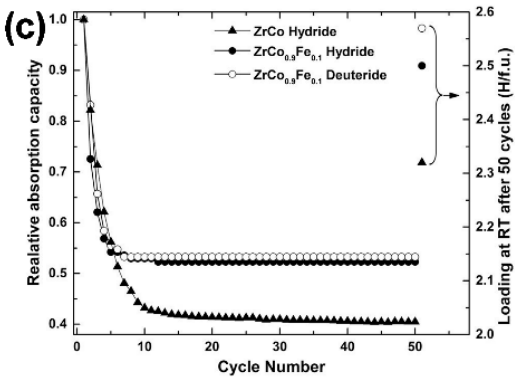

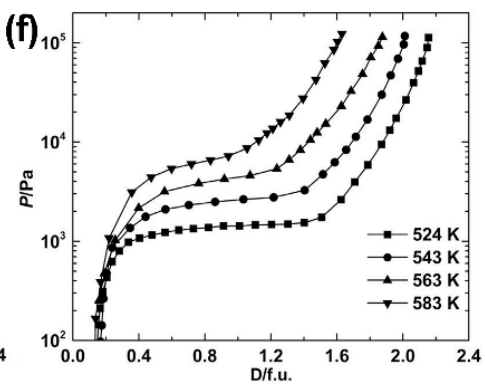

(d)

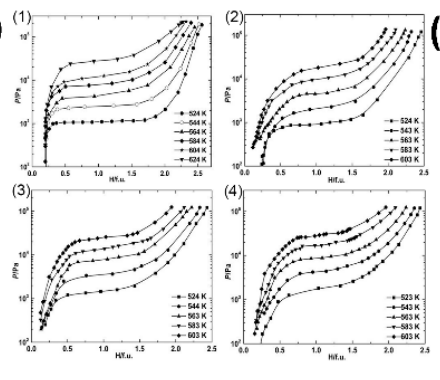

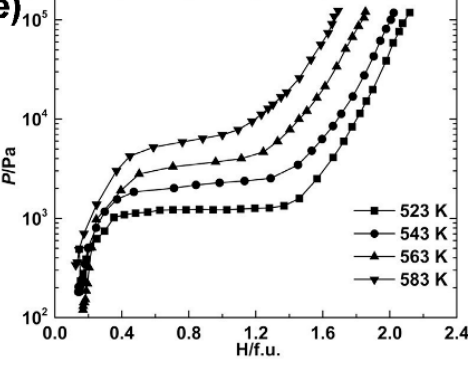

Figure 3. (a) Scanning electron microscope (SEM) images of $\mathrm{ZrCo}_{1-\mathrm{x}} \mathrm{Ni}_{\mathrm{x}}$ alloys at magnifications of 5000x: (1) $x=0,(2) x=0.1,(3) x=0.2,(4) x=0.3$, (5) and (6) hydride of ZrCo at magnifications of $5000 \times$ and $10,000 \times$, respectively; (b) effect of hydrogen absorption-desorption cycles on the storage capacity of $\mathrm{ZrCo}_{1-\mathrm{x}} \mathrm{Ni}_{\mathrm{x}}$ alloys at $583 \mathrm{~K}$ [68]; (c) effect of hydrogen/deuterium absorption-desorption cycles on the storage capacity of $\mathrm{ZrCo}_{0.9} \mathrm{Fe}_{0.1}$ and $\mathrm{ZrCo}$ alloys at $583 \mathrm{~K}$ [47]; (d) hydrogen desorption pressure-composition isotherms for $\mathrm{ZrCo}_{1-\mathrm{x}} \mathrm{Ni}_{\mathrm{x}}-\mathrm{H}_{2}$ systems: (1) $\mathrm{x}=0$, (2) $\mathrm{x}=0.1$, (3) $\mathrm{x}=0.2$, and (4) $\mathrm{x}=0.3$ [68]; (e) hydrogen desorption pressure-composition isotherms for $\mathrm{ZrCo}_{0.9} \mathrm{Fe}_{0.1}-\mathrm{H}_{2}$ systems; (f) deuterium desorption pressure-composition isotherms for $\mathrm{ZrCo}_{0.9} \mathrm{Fe}_{0.1}-\mathrm{D}_{2}$ systems [47].

$\mathrm{Fe}$ is another substitute element for $\mathrm{Co}$; the effects of $\mathrm{Fe}$ substitution for $\mathrm{Co}$ on the pressure-composition isotherms and anti-disproportionation are shown in Figure 3c,e,f. After 50 hydrogen/deuterium absorption-desorption cycles at $583 \mathrm{~K}$, the storage capacity of the $\mathrm{ZrCo}-\mathrm{H}_{2}$ system decreases by $19.2 \%$, while the storage capacities of the $\mathrm{ZrCo}_{0.9} \mathrm{Fe}_{0.1}-\mathrm{H}_{2}$ system and the $\mathrm{ZrCo}_{0.9} \mathrm{Fe}_{0.1}-\mathrm{D}_{2}$ system are $8.5 \%$ and $10.1 \%$, respectively. In general, the final storage capacity of the $\mathrm{ZrCo}_{0.9} \mathrm{Fe}_{0.1}$ alloy is significantly higher than that of the $\mathrm{ZrCo}$ alloy, which is similar to that in $\mathrm{Ni}$-doped $\mathrm{ZrCoH}_{3}$. The lattice parameters and cell volume of the $\mathrm{ZrCo}_{0.9} \mathrm{Fe}_{0.1}$ alloy are larger than those of the $\mathrm{ZrCo}$ alloy; however, as shown in Table 2, the occupancy of the $8 \mathrm{e}$ site significantly reduces from $3.8 \%$ to $1.8 \%$, and the length of $\mathrm{Zr}-\mathrm{D}$ (8e) also increases from $1.937 \AA$ to $2.201 \AA$. Both of them significantly enhance the hydrogen anti-disproportionation of the alloy [47]. 
Table 2. Rietveld optimization results for neutron diffraction data of $\mathrm{ZrCo}_{1-x} \mathrm{Fe}_{\mathrm{x}}$ and $\mathrm{ZrCo}_{1-\mathrm{x}} \mathrm{Ni}_{\mathrm{x}}$ hydride $[47,58]$.

\begin{tabular}{|c|c|c|c|c|c|c|}
\hline \multirow{2}{*}{ Parameters } & & \multicolumn{2}{|c|}{$x$ in $\mathrm{ZrCo}_{1-\mathrm{x}} \mathrm{Fe}_{\mathrm{x}}$ Deuterides } & \multicolumn{3}{|c|}{$x$ in $\mathrm{ZrCo}_{1-x} \mathrm{Ni}_{x}$ Deuterides } \\
\hline & & 0 & 0.1 & 0.1 & 0.2 & 0.3 \\
\hline $\mathrm{D} 1\left(4 \mathrm{c}_{2}\right)(0 \mathrm{y} 1 / 4)$ & $\mathrm{y}$ & $0.9269 \pm 0.0039$ & $0.9279 \pm 0.0003$ & $0.9300 \pm 0.0005$ & $0.9282 \pm 0.0003$ & $0.9291 \pm 0.0003$ \\
\hline Occupancy (\%) & & 29.3 & 29.9 & 30.8 & 30.1 & 31.1 \\
\hline \multirow[t]{2}{*}{$\mathrm{D} 2\left(8 \mathrm{f}_{1}\right)(0 \mathrm{yz})$} & $\mathrm{y}$ & $0.3119 \pm 0.002$ & $0.3119 \pm 0.0002$ & $0.3125 \pm 0.0003$ & $0.3122 \pm 0.0002$ & $0.3119 \pm 0.0002$ \\
\hline & $\mathrm{z}$ & $0.5047 \pm 0.0006$ & $0.5041 \pm 0.0005$ & $0.5047 \pm 0.0007$ & $0.5062 \pm 0.0004$ & $0.5053 \pm 0.0004$ \\
\hline Occupancy (\%) & & 66.9 & 68.3 & 66.4 & 67.2 & 66.4 \\
\hline D3 (8e) $\left(\begin{array}{llllll}x & 0 & 0\end{array}\right)$ & $x$ & $0.2219 \pm 0.0081$ & $0.3725 \pm 0.0139$ & $0.2243 \pm 0.0139$ & $0.2549 \pm 0.0088$ & $0.2637 \pm 0.0095$ \\
\hline Occupancy (\%) & & 3.8 & 1.8 & 2.8 & 2.7 & 2.5 \\
\hline Zr-D distance $(\AA)$ & & $1.937 \pm 0.012$ & $2.201 \pm 0.030$ & $1.940 \pm 0.020$ & $1.994 \pm 0.014$ & $2.022 \pm 0.015$ \\
\hline $\mathrm{R}_{\mathrm{p}}(\%)$ & & 3.29 & 1.93 & 6.7 & 1.81 & 2.13 \\
\hline $\mathrm{R}_{\mathrm{wp}}(\%)$ & & 4.15 & 2.45 & 9.86 & 2.36 & 2.89 \\
\hline$R_{\exp }(\%)$ & & 3.61 & 1.81 & 2.46 & 1.32 & 1.4 \\
\hline
\end{tabular}




\subsection{Double Doping of Ti/Fe and Ti/Ni}

Researchers designed an alloy with a composition of $\mathrm{Zr}_{0.8} \mathrm{Ti}_{0.2} \mathrm{Co}_{1-\mathrm{x}} \mathrm{Fe}_{\mathrm{x}}(\mathrm{x}=0.1-0.3)$ to further improve the overall hydrogen storage properties of $\mathrm{ZrCo}$-based alloys. The microstructure and cyclic hydriding kinetic property are shown in Figure $4 \mathrm{a}-\mathrm{d}$. It was found that after five absorption-desorption cycles at $573 \mathrm{~K}$, the hydrogen storage retention rate in Fe-doped $\mathrm{ZrCoH}_{3}$ is $87 \%(x=0.1), 82 \%(x=0.2)$, and $80 \%(x=0.3)$, whereas the highest retention rate in undoped $\mathrm{ZrCoH}_{3}$ is $88 \%$. The atomic radius of the Fe element is $1.27 \AA$, which is slightly larger than that of the Co element. As shown in Table 1, we can see that the unit cell volume and lattice parameters of the $\mathrm{ZrCo}$ phase of the $\mathrm{Zr}_{0.8} \mathrm{Ti}_{0.2} \mathrm{Co}_{1-\mathrm{x}} \mathrm{Fe}_{\mathrm{x}}$ alloy increase gradually as the Fe content increases. In fact, it is extremely difficult to prepare a single phase of $\mathrm{ZrCo}$, which is accompanied by the formation of the $\mathrm{ZrCo}_{2}$ phase. XRD patterns show that cubic phase $\mathrm{ZrCo}$ and secondary Laves phase of $\mathrm{Zr}(\mathrm{Co}, \mathrm{Fe})_{2}$ and $\mathrm{Zr}_{2} \mathrm{Co}$ are formed in the $\mathrm{Zr}_{0.8} \mathrm{Ti}_{0.2} \mathrm{Co}_{1-\mathrm{x}} \mathrm{Fe}_{\mathrm{x}}$ alloy. Moreover, the contents of the secondary phase increase with the increase in $\mathrm{Fe}$ substitution. Although the Laves phase provides abundant phase interfaces as hydrogen diffusion channels to improve the hydriding kinetic property, the anti-disproportionation and hydrogen storage capacity are weakened at the same time [75].
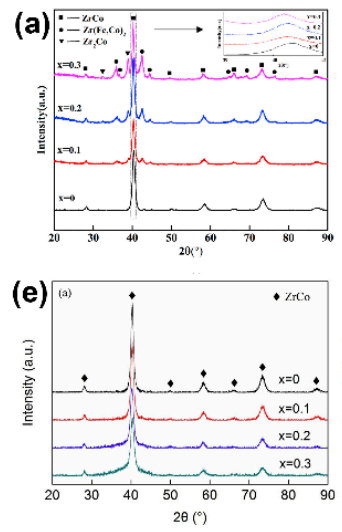
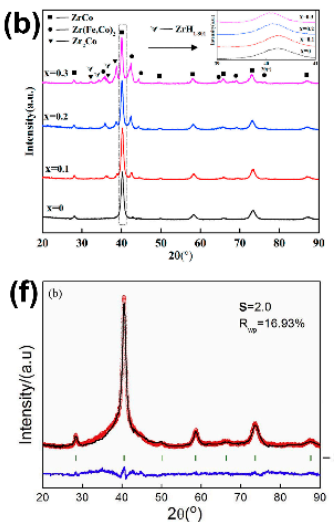
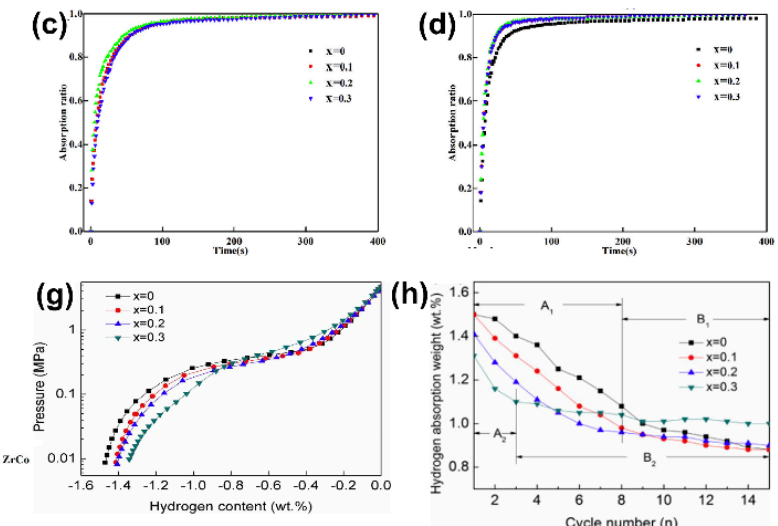

Figure 4. (a) XRD patterns of $\mathrm{Zr}_{0.8} \mathrm{Ti}_{0.2} \mathrm{Co}_{1-\mathrm{x}} \mathrm{Fe}_{\mathrm{x}}(\mathrm{x}=0-0.3)$ alloys after arc melting; (b) XRD patterns of $\mathrm{Zr}_{0.8} \mathrm{Ti}_{0.2} \mathrm{Co}_{1-\mathrm{x}} \mathrm{Fe}_{\mathrm{x}}(\mathrm{x}=0-0.3)$ alloys after 5 hydrogen absorption-desorption cycles; (c) the second hydriding kinetic curve of $\mathrm{Zr}_{0.8} \mathrm{Ti}_{0.2} \mathrm{Co}_{1-\mathrm{x}} \mathrm{Fe}_{\mathrm{x}}(\mathrm{x}=0-0.3)$ alloys at $573 \mathrm{~K}$; (d) the fifth hydriding kinetic curve of $\mathrm{Zr}_{0.8} \mathrm{Ti}_{0.2} \mathrm{Co}_{1-\mathrm{x}} \mathrm{Fe}_{\mathrm{x}}\left(\mathrm{x}=0-0.3\right.$ ) alloys at $573 \mathrm{~K}$ [75]; (e) XRD patterns of $\mathrm{Zr}_{0.8} \mathrm{Ti}_{0.2} \mathrm{Co}_{1-\mathrm{x}} \mathrm{Ni}_{\mathrm{x}}$ $(\mathrm{x}=0-0.3)$ alloys; (f) XRD pattern and Rietveld analysis pattern of $\mathrm{Zr}_{0.8} \mathrm{Ti}_{0.2} \mathrm{Co}_{0.7} \mathrm{Ni}_{0.3} ;(\mathrm{g})$ desorption Pressure-composition-temperature (PCT) curves for $\mathrm{Zr}_{0.8} \mathrm{Ti}_{0.2} \mathrm{Co}_{1-\mathrm{x}} \mathrm{Ni}_{\mathrm{x}}-\mathrm{H}_{2}(\mathrm{x}=0-0.3)$ systems at $673 \mathrm{~K}$; (h) cyclic stability curve of the $\mathrm{Zr}_{0.8} \mathrm{Ti}_{0.2} \mathrm{Co}_{1-\mathrm{x}} \mathrm{Ni}_{\mathrm{x}}$ alloy at $573 \mathrm{~K}$ [77].

Similarly, the substitution of the single elements Ni for $\mathrm{Co}$ and $\mathrm{Ti}$ for $\mathrm{Zr}$ can improve the cyclic stability of the $\mathrm{ZrCo}$ alloy to some extent. Therefore, $\mathrm{Zr}_{0.8} \mathrm{Ti}_{0.2} \mathrm{Co}_{1-\mathrm{x}} \mathrm{Ni}_{\mathrm{x}}(\mathrm{x}=0-0.3)$ alloys were prepared by vacuum arc melting, as shown in Figure $4 \mathrm{e}-\mathrm{h}$. After 15 hydrogen absorption-desorption cycles at $573 \mathrm{~K}$, the hydrogen storage retention rates are $58.7 \%(\mathrm{x}=0), 58.7 \%(\mathrm{x}=0.1), 63.8 \%(\mathrm{x}=0.2)$, and $76.3 \%$ $(\mathrm{x}=0.3)$ [77].

It can be seen that the $\mathrm{Ni}$ substitution of $\mathrm{Zr}_{0.8} \mathrm{Ti}_{0.2} \mathrm{Co}$ further improves its anti-disproportionation performance. However, the hydrogen desorption curve at $673 \mathrm{~K}$ shows that the anti-disproportionation of the alloy is slightly deteriorated by the partial substitution of the Ni element for the Co element. As shown in Table 1, as the Ni content increases, the lattice parameters and cell volume decrease. At $573 \mathrm{~K}$, the curves are clearly characterized by two stages (part A with a rapid decrease and part B with a slow decline in hydrogen absorption capacity). As shown in Figure $4 \mathrm{~h}$, the cyclic stability of the alloy is obviously improved with the Ni partial substitution, and Jing et al. believed this was related to the improvement of the anti-pulverization of the alloy. In contrast, the decrease in cyclic stability of the alloy at $673 \mathrm{~K}$ indicates that hydrogen disproportionation is the major factor leading to the deterioration of the hydrogen storage properties [77]. 


\subsection{Anti-Disproportionation Mechanism of Doping}

It is helpful to solve the problem of disproportionation fundamentally, by probing into the internal disproportionation mechanism of ZrCo-based alloys [78]. These first-principle calculations were performed with the density functional theory (DFT) as implemented in the Vienna Ab-initio Simulation Package (VASP). Through summarizing first-principle simulations [46,48,79-95], it has been shown that, in the $\mathrm{ZrCo}-\mathrm{H}_{2}$ system, the binding of $\mathrm{H}$ with $\mathrm{Zr}$ (or its substitute elements) shows a strong ion and weak covalence bond, and the binding of $\mathrm{H}$ with $\mathrm{Co}$ (or its substitute elements) shows a weak ion and strong covalence bond. In addition, the $\mathrm{Zr}-\mathrm{D}$ distance in the 8e sites of $\mathrm{ZrCoD}_{3}$ is smaller than the $\mathrm{Zr}-\mathrm{D}$ distance of $\mathrm{ZrD}_{2}$ [58]. Therefore, when disproportionation occurs, it is more likely to form $\mathrm{ZrH}_{2}$. The calculated binding energies of the $\mathrm{H}$ atoms at the $4 \mathrm{c}_{2}$ and $8 \mathrm{f}_{1}$ sites are $-0.58 \mathrm{eV}$ and $-0.48 \mathrm{eV}$, respectively. The $\mathrm{H}$ binding energy at the $8 \mathrm{e}$ site is $0.05 \mathrm{eV}\left(\mathrm{E}_{1}\right)$ or $0.28 \mathrm{eV}\left(\mathrm{E}_{2}\right)$. $\mathrm{E}_{1}$ represents the binding energy in which the nearest $\mathrm{H}\left(4 \mathrm{c}_{2}\right)$ atom of this $8 \mathrm{e}$ site diffuses into the 8e site, and $\mathrm{E}_{2}$ represents the binding energy in which an additional $\mathrm{H}$ atom is inserted into one 8e site. It is evident that the $4 \mathrm{c}_{2}$ and $8 \mathrm{f}_{1}$ sites are more stable for the $\mathrm{H}$ atom than the $8 \mathrm{e}$ site. Hence, $\mathrm{H}$ atoms occupy only $4 \mathrm{c}_{2}$ and $8 \mathrm{f}_{1}$ sites under ideal conditions [60]. The number of $\mathrm{H}$ atoms occupying $8 \mathrm{e}$ is much lower than that of $\mathrm{H}$ atoms occupying the other two sites, accounting for only about $4 \%$ of the total hydrogen.

The relationship between the size of the $8 \mathrm{e}$ site and the substitution atom can be seen from the simulation in Figure $5 \mathrm{~b}, \mathrm{~d}$. The substitution of the $\mathrm{Zr}$ element is favorable for improving the anti-disproportionation of the ZrCo alloy, whereas the substitution from Co may not be suitable to enhance the anti-disproportionation [60,95]. Obviously, if the volume of the 8e site is small, it is hard for the $\mathrm{H}$ atom to diffuse into the 8e site, resulting in a significant decrease in the proportion of hydrogen atoms in the $8 \mathrm{e}$ site. The $\mathrm{H}$ diffusion process in undoped, and doped $\mathrm{ZrCoH}_{3}$ is investigated in Figure 5a. Nonetheless, from the above introduction of the Ni and Fe substitution experiments, we can conclude that the Co element substitution also enhances the ability of anti-disproportionation. Therefore, there must be other factors contributing to the anti-disproportionation.

(a)
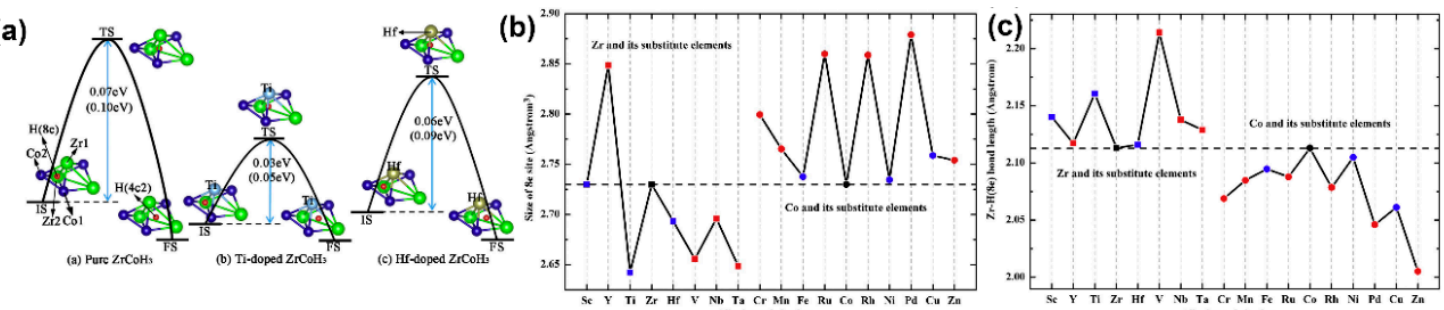

(d)
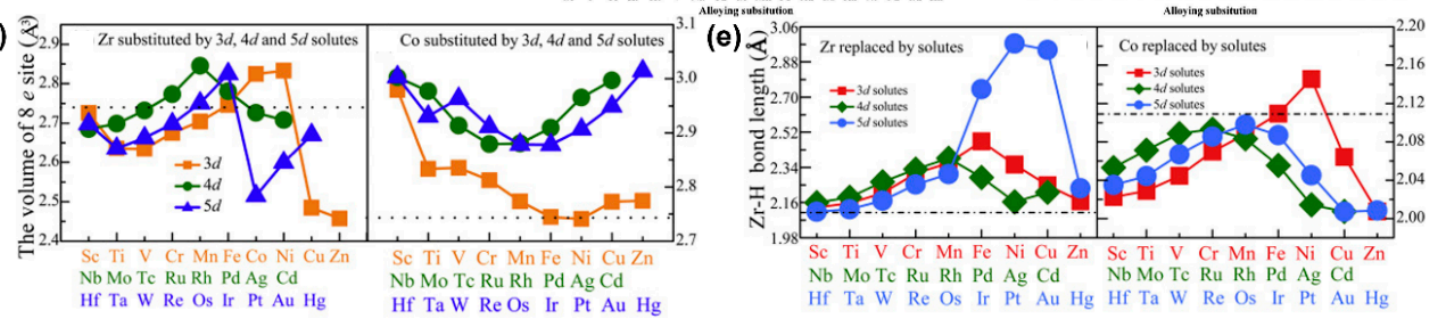

Figure 5. (a) Schematic diagram of $\mathrm{H}$ diffusion from the $8 \mathrm{e}$ site to the $4 \mathrm{c}_{2}$ site in undoped, Ti-doped, and Hf-doped $\mathrm{ZrCoH}_{3}$; (b) sizes of the 8e site in the undoped and doped $\mathrm{ZrCoH}_{3}$ crystal; (c) the $\mathrm{Zr}-\mathrm{H}$ (8e) bond length in the tetrahedron of undoped and doped $\mathrm{ZrCoH}_{3}$ with the $8 \mathrm{e}$ site occupied by a $\mathrm{H}$ atom [60]; (d) volumes of the tetrahedron when one of the $\mathrm{Zr} / \mathrm{Co}$ atoms in the tetrahedron is substituted by $3 \mathrm{~d}, 4 \mathrm{~d}$, and $5 \mathrm{~d}$ transition alloying solutes; (e) the bond lengths of $\mathrm{Zr}$ and $\mathrm{H}$ at the $8 \mathrm{e}$ site (at the center of the tetrahedron) when one of the $\mathrm{Zr} / \mathrm{Co}$ atoms in the tetrahedron is substituted by $3 \mathrm{~d}, 4 \mathrm{~d}$, and $5 \mathrm{~d}$ transition alloying solutes [95].

The $\mathrm{Zr}-\mathrm{H}$ (8e) bond length of $\mathrm{ZrCoH}_{3}$ plays a key role in the anti-disproportionation process; the longer the distance of $\mathrm{Zr}-\mathrm{H}(8 \mathrm{e})$, the stronger the inhibition of hydrogen disproportionation can become $[47,48,58,60,96]$. This can also be seen from the simulation results shown in Figure 5c,e. 
The length of the $\mathrm{Zr}-\mathrm{H}$ (8e) bond in the $\mathrm{Zr}$-substituted $\mathrm{ZrCoH}_{3}$ is longer than that in the undoped $\mathrm{ZrCoH}_{3}$, whereas the length of the $\mathrm{Zr}-\mathrm{H}$ (8e) bond in the Co-substituted $\mathrm{ZrCoH}_{3}$ is shorter than that in the undoped $\mathrm{ZrCoH}_{3}$ [60].

At the same time, the occupancy of $\mathrm{H}(8 \mathrm{e})$ is also an important factor in improving the ability of anti-disproportionation [91]. For instance, Fe substitution has the larger size of 8e and the shorter length of the $\mathrm{Zr}-\mathrm{H}$ (8e) from the simulation results (Figure 5b,c). Theoretically, Fe-substituted $\mathrm{ZrCoH}_{3}$ should decrease the anti-disproportionation performance. Nonetheless, Jat et al. [47] found that the $\mathrm{ZrCo}_{0.9} \mathrm{Fe}_{0.1}$ alloy has better anti-disproportionation than the $\mathrm{ZrCo}$ alloy. The neutron diffraction studies reveal that the occupancy of $\mathrm{H}$ (8e) of $\mathrm{ZrCo}_{0.9} \mathrm{Fe}_{0.1} \mathrm{D}_{3}$ is $1.8 \%$, which is lower than $\sim 3.8 \%$ of $\mathrm{ZrCoD}_{3}$. The lower occupancy of $\mathrm{H}(8 \mathrm{e})$ explains the higher durability of the $\mathrm{ZrCo}_{0.9} \mathrm{Fe}_{0.1}$ alloy against disproportionation.

The effects of $\mathrm{Zr}-\mathrm{H}$ (8e) spacing, 8e site size, and occupancy of $\mathrm{H}$ (8e) on the anti-disproportionation performance are likewise relatively consistent with the above experimental results.

\section{Conclusions and Outlook}

This review presents an overview of the anti-disproportionation of $\mathrm{ZrCo}$-based alloys along with a discussion of the disproportionation mechanism. At present, the performance of the $\mathrm{ZrCo}$-based alloy cannot meet requirements, and it is unable to meet the high-pressure transportation required by the storage and delivery system at the current working temperature that suppresses disproportionation, or eliminate the disproportionation at the high temperature that meets the storage and transport rate. Obviously, element substitution is the most tried and promising way to improve the anti-disproportionation of the ZrCo alloy, compared to other methods [64,67,97-104]. To date, many experiments have shown that samples with smaller lattice parameters and cell volume have the expected anti-disproportionation ability. Nevertheless, it is only the appearance that describes the anti-disproportionation performance, and it is not the determinant of a stronger anti-disproportionation performance caused by element substitution [105-107]. For instance, when the Ni element substitutes for the Co element, the doped sample has a better cyclic stability and anti-disproportionation performance, but the lattice parameters and cell volume increase with Ni substitution. Obviously, this does not correspond to the above expectation, the fundamental reasons of the anti-disproportionation being that the occupancy of $\mathrm{H}$ (8e) decreases from $\sim 3.8 \%$ to $\sim 2.5 \%\left(\mathrm{ZrCo}_{0.7} \mathrm{Ni}_{0.3} \mathrm{D}_{3}\right)$, and the $\mathrm{Zr}-\mathrm{D}$ (8e) distance increases from $1.937 \AA$ to $2.022 \AA\left(\mathrm{ZrCo}_{0.7} \mathrm{Ni}_{0.3} \mathrm{D}_{3}\right)$ compared with $\mathrm{ZrCoD}_{3}$ [58]. In other words, the length of the $\mathrm{Zr}-\mathrm{H}$ (8e) bond is an important factor affecting the disproportionation activation energy; similarly, the size of the 8e site reflects the ability of the $\mathrm{H}$ atom to diffuse out and diffuse into the 8e site, and the occupancy of $\mathrm{H}(8 \mathrm{e})$ is also an important factor in improving the ability of anti-disproportionation. Hence, the instability occupied by the hydrogen atom on the 8e site can be seen as the driving force of disproportionation.

However, where does the $\mathrm{H}$ atom of the $8 \mathrm{e}$ site come from? The answer is perhaps the $4 \mathrm{c}_{2}$ site or the $8 \mathrm{f}_{1}$ site, shown in Figure 1c or Figure 1e,f. It was found from Table 2 that Ni/Fe substitutions decrease the occupancy of $\mathrm{H}(8 \mathrm{e})$, while the occupancy of $\mathrm{H}\left(4 \mathrm{c}_{2}\right)$ and $\mathrm{H}\left(8 \mathrm{f}_{1}\right)$ increases. We can attempt to influence the occupancy of $\mathrm{H}(8 \mathrm{e})$ by changing adjacent sites, such as the distance of $\mathrm{H}(8 \mathrm{e})$ and $\mathrm{H}\left(4 \mathrm{c}_{2}\right)$. It can be predicted that, through an in-depth study of the disproportionation mechanism, the optimal element substitution can be selected by calculation and experimental methods to suppress the hydrogen atoms occupying the $8 \mathrm{e}$ sites, so as to further improve the anti-disproportionation effect of ZrCo-based alloys.

Author Contributions: Conceptualization, M.W. and J.S.; software, M.W.; validation, M.W. and J.W.; formal analysis, M.W. and J.W.; investigation, M.W.; resources, J.S. and J.W.; data curation, M.W.; writing-original draft preparation, M.W.; writing_-review and editing, M.W., J.W., X.T., P.L. and C.H.; supervision, J.S., J.W. and X.T.; project administration, J.S.; funding acquisition, J.S. All authors have read and agreed to the published version of the manuscript. 
Funding: This work was supported by the National Natural Science Foundation of China, Grant No. U1832178, and the Science and Technology Department of Sichuan Province, Grant No. 2018JZ0012.

Conflicts of Interest: The authors declare no conflict of interest.

\section{References}

1. Kou, H.; Luo, W.; Tang, T.; Huang, Z.; Sang, G.; Wang, H.; Chen, C.; Zhang, G.; Bao, J.; Xue, Y. Temperature-hydrogen pressure phase boundaries and corresponding thermodynamics for $\mathrm{ZrCoH}$ system. Int. J. Hydrogen Energy 2018, 43, 16169-16179. [CrossRef]

2. Shmayda, W.T.; Heics, A.G.; Kherani, N.P. Comparison of uranium and zirconium cobalt for tritium storage. J. Less Common Met. 1990, 162, 117-127. [CrossRef]

3. Glugla, M.; Busigin, A.; Dörr, L.; Haange, R.; Hayashi, T.; Kveton, O.; Lässer, R.; Murdoch, D.K.; Nishi, M.; Penzhorn, R.D.; et al. The tritium fuel cycle of ITER-FEAT. Fusion Eng. Des. 2001, 58-59, 349-353. [CrossRef]

4. Glugla, M.; Murdoch, D.K.; Antipenkov, A.; Beloglazov, S.; Cristescu, I.; Cristescu, I.R.; Day, C.; Laesser, R.; Mack, A. ITER fuel cycle R\&D: Consequences for the design. Fusion Eng. Des. 2006, 81, 733-744.

5. Haldar, S.; Mukherjee, S.; Ahmed, F.; Singh, C.V. A first principles study of hydrogen storage in lithium decorated defective phosphorene. Int. J. Hydrogen Energy 2017, 42, 23018-23027. [CrossRef]

6. Liu, J.; Li, K.; Cheng, H.; Yan, K.; Wang, Y.; Liu, Y.; Jin, H.; Zheng, Z. New insights into the hydrogen storage performance degradation and $\mathrm{Al}$ functioning mechanism of $\mathrm{LaNi}_{5-\mathrm{x}} \mathrm{Al}_{\mathrm{x}}$ alloys. Int. J. Hydrogen Energy 2017, 42, 24904-24914. [CrossRef]

7. Hayashi, T.; Suzuki, T.; Konishi, S.; Yamanishi, T.; Nishi, M.; Kurita, K. Development of ZrCo Beds for ITER Tritium Storage and Delivery. Fusion Sci. Technol. 2002, 41, 801-804. [CrossRef]

8. Devillers, M.; Sirch, M.; Penzhorn, R.D. Hydrogen-induced disproportionation of the intermetallic zirconium-cobalt compound ZrCo. Chem. Mater. 1992, 4, 631-639. [CrossRef]

9. Jat, R.A.; Pati, S.; Parida, S.C.; Agarwal, R.; Mukerjee, S.K. Synthesis, characterization and hydrogen isotope storage properties of Zr-Ti-Co ternary alloys. Int. J. Hydrogen Energy 2017, 42, 2248-2256. [CrossRef]

10. Feng, W.; Li, R.; Ding, C.; Tang, W.; Wang, Y.; Xu, S.; Yu, R.; Ying, W. Recent progress on the hydrogen storage properties of ZrCo-based alloys applied in International Thermonuclear Experimental Reactor (ITER). Prog. Nat. Sci. 2017, 27, 58-65.

11. Koultoukis, E.D.; Makridis, S.S.; Pavlidou, E.; de Rango, P.; Stubos, A.K. Investigation of $\mathrm{ZrFe}_{2}$-type materials for metal hydride hydrogen compressor systems by substituting Fe with Cr or V. Int. J. Hydrogen Energy 2014, 39, 21380-21385. [CrossRef]

12. Nowotny, J.; Hoshino, T.; Dodson, J.; Atanacio, A.J.; Ionescu, M.; Peterson, V.; Prince, K.E.; Yamawaki, M.; Bak, T.; Sigmund, W.; et al. Towards sustainable energy. Generation of hydrogen fuel using nuclear energy. Int. J. Hydrogen Energy 2016, 41, 12812-12825. [CrossRef]

13. Holtkamp, N. An overview of the ITER project. Fusion Eng. Des. 2007, 82, 427-434. [CrossRef]

14. Cho, S.; Chang, M.H.; Yun, S.H.; Kang, H.G.; Chung, H.; Song, K.M.; Koo, D.; Chung, D.; Jeong, D.; Lee, M.K.; et al. R\&D Activities on the Tritium Storage and Delivery System in Korea. Fusion Sci. Technol. 2011, 60, 1077-1082.

15. Glugla, M.; Lässer, R.; Dörr, L.; Murdoch, D.K.; Haange, R.; Yoshida, H. The inner deuterium/tritium fuel cycle of ITER. Fusion Eng. Des. 2003, 69, 39-43. [CrossRef]

16. He, H.; Luo, W.H.; Kou, H.Q. Review of studies on improving the anti-disproportionation properties of ZrCo tritium storage alloys: Crystal structure, dehydrogenation thermodynamics and disproportionation kinetics. Mater. Rev. 2017, 31, 4-11.

17. Kou, H.; Luo, W.; Huang, Z.; Sang, G.; Hu, C.; Chen, C.; Zhang, G.; Luo, D.; Liu, M.; Zheng, S. Effects of temperature and hydrogen pressure on the activation behavior of ZrCo. Int. J. Hydrogen Energy 2016, 41, 10811-10818. [CrossRef]

18. Kou, H.; Sang, G.; Luo, W.; Huang, Z.; Meng, D.; Zhang, G.; Deng, J.; Luo, Z.; He, W.; Hu, C. Comparative study of full-scale thin double-layered annulus beds loaded with $\mathrm{ZrCo}, \mathrm{Zr}_{0.8} \mathrm{Hf}_{0.2} \mathrm{Co}$ and $\mathrm{Zr}_{0.8} \mathrm{Ti}_{0.2} \mathrm{Co}$ for recovery and delivery of hydrogen isotopes. Int. J. Hydrogen Energy 2015, 40, 10923-10933. [CrossRef]

19. Durbin, D.J.; Malardier-Jugroot, C. Review of hydrogen storage techniques for on board vehicle applications. Int. J. Hydrogen Energy 2013, 38, 14595-14617. [CrossRef] 
20. Kou, H.; Huang, Z.; Luo, W.; Ge, S.; Meng, D.; Luo, D.; Zhang, G.; Hao, C.; Ying, Z.; Hu, C. Experimental study on full-scale $\mathrm{ZrCo}$ and depleted uranium beds applied for fast recovery and delivery of hydrogen isotopes. Appl. Energy 2015, 145, 27-35. [CrossRef]

21. Cui, Y.; Zeng, X.; Kou, H.; Ding, J.; Wang, F. Numerical modeling of heat transfer during hydrogen absorption in thin double-layered annular ZrCo beds. Results Phys. 2018, 9, 640-647. [CrossRef]

22. Longhurst, G.R. Pyrophoricity of Tritium-Storage Bed Materials. Fusion Technol. 1988, 14, 750-755. [CrossRef]

23. Wang, L.; Ding, J.; Huang, X.; Song, K.; Liu, B.; Zeng, X. Influence of Ti/Hf doping on hydrogen storage performance and mechanical properties of $\mathrm{ZrCo}$ compounds: A first principle study. Int. J. Hydrogen Energy 2018, 43, 13328-13338. [CrossRef]

24. Kou, H.; Luo, W.; Huang, Z.; Sang, G.; Meng, D.; Zhang, G.; Chen, C.; Luo, D.; Hu, C. Fabrication and experimental validation of a full-scale depleted uranium bed with thin double-layered annulus configuration for hydrogen isotopes recovery and delivery. Energy 2015, 90, 588-594. [CrossRef]

25. Schlapbach, L.; Züttel, A. Hydrogen-storage materials for mobile applications. In Materials for Sustainable Energy; Co-Published with Macmillan Publishers Ltd.: London, UK, 2010; pp. 265-270.

26. Zhang, G.H. Preparation and Study of Hydrogen-Resistant Tritium Storage Alloy of ZrCo Series. Ph.D. Thesis, University of Science and Technology of China, Hefei, China, 2015.

27. Zhang, G.H.; Sang, G. Study on anti-hydrogen-induced disproportionation mechanism of Ti-modified ZrCo tritium storage alloy. Nucl. Power Eng. 2016, 37, 54-56.

28. Zhang, G.H.; Tang, T.; Sang, G.; Xiong, Y.F.; Kou, H.Q.; Wu, W.Q.; Wei, Y.J. Hydrogen absorption behavior and influence mechanism of Ti element modified ZrCo alloy in CO impurity atmosphere. Rare Metal. Mater. Eng. 2017, 46, 3366-3373.

29. Kou, H.Q.; Luo, W.H.; Tang, T.; Huang, Z.Y.; Sang, G.; Zhang, G.H.; He, H. Non-equilibrium temperature-hydrogen pressure phase boundary and thermodynamics of dehydrogenation and disproportionation reaction in zrco-h system. In Proceedings of the Second China Tritium Science and Technology Academic Exchange Conference, Chengdu, China, 24-26 August 2017; p. 1.

30. Devillers, M.; Sirch, M.; Bredendiek-Kaemper, S.; Penzhorn, R.D. Characterization of the zirconium-cobalt (ZrCo)-hydrogen system in view of its use for tritium storage. Chem. Mater. 1990, 2, 255-262. [CrossRef]

31. Nagasaki, T.; Konishi, S.; Katsuta, H.; Naruse, Y. A Zirconium-Cobalt Compound as the Material for a Reversible Tritium Getter. Fusion Technol. 1986, 9, 506-509. [CrossRef]

32. Maynard, K.J.; Shmayda, W.T.; Heics, A.G. Tritium Aging Effects in Zirconium-Cobalt. Fusion Technol. 1995, 28, 1391-1398. [CrossRef]

33. Le Guyadec, F.; Génin, X.; Bayle, J.P.; Dugne, O.; Duhart-Barone, A.; Ablitzer, C. Pyrophoric behaviour of uranium hydride and uranium powders. J. Nucl. Mater. 2010, 396, 294-302. [CrossRef]

34. Tsuchiya, K.; Kabutomori, T.; Kawamura, H. Study of the high efficiency of ZrNi alloys for tritium gettering properties. Fusion Eng. Des. 2001, 58-59, 401-405. [CrossRef]

35. Bhattacharyya, R.; Mohan, S. Solid state storage of hydrogen and its isotopes: An engineering overview. Renew. Sustain. Energy Rev. 2015, 41, 872-883. [CrossRef]

36. Chung, D.; Jeong, D.; Koo, D.; Yoshida, H.; Song, K.-M.; Chang, M.H.; Kang, H.-G.; Yun, S.-H.; Cho, S.; Jung, K.J.; et al. Fusion fuel gas recovery and delivery characteristics on a tray-type ZrCo bed. Fusion Eng. Des. 2011, 86, 2233-2236. [CrossRef]

37. Shim, M.; Chung, H.; Kim, K.; Yoshida, H.; Cho, S.; Kim, D.; Ahn, M. Heat analysis on the initial reference design of ZrCo hydride beds for ITER. Fusion Eng. Des. 2008, 83, 1433-1437. [CrossRef]

38. Konishi, S.; Nagasaki, T.; Yokokawa, N.; Naruse, Y. Development of zirconium-cobalt beds for recovery, storage and supply of tritium. Fusion Eng. Des. 1989, 10, 355-358. [CrossRef]

39. Konishi, S.; Nagasaki, T.; Hayashi, T.; Okuno, K. Equilibrium hydrogen pressure on the solid solutions of ZrCo-HfCo intermetallic compounds. J. Nucl. Mater. 1995, 223, 300-304. [CrossRef]

40. Penzhorn, R.D.; devillers, M.; Sirch, M. Evaluation of ZrCo and other getters for tritium handling and storage. J. Nucl. Mater. 1990, 170, 217-231. [CrossRef]

41. Guo, X.M.; Wang, S.M.; Liu, X.P.; Li, Z.N.; Lv, F.; Hao, L.; Mi, Q.; Jiang, L.J. Study on hydrogen storage and emission isotope of ZrCo alloy. Metal. Funct. Mater. 2011, 18, 41-44.

42. Kou, H.Q. Study on Hydrogen Isotope Storage Bed with the Order of 100 Grams Tritium. Ph.D. Thesis, Beijing Institute of Technology, Beijing, China, 2016. 
43. Naik, Y.; Rama Rao, G.A.; Venugopal, V. Zirconium-cobalt intermetallic compound for storage and recovery of hydrogen isotopes. Intermetallics 2001, 9, 309-312. [CrossRef]

44. Hara, M.; Okabe, T.; Mori, K.; Watanabe, K. Kinetics and mechanism of hydrogen-induced disproportionation of ZrCo. Fusion Eng. Des. 2000, 49-50, 831-838. [CrossRef]

45. Lv, L.J. Study on Improvement of Properties of $\mathrm{LaNi}_{4.25} \mathrm{Al}_{0.75}$ and $\mathrm{ZrCo}$ Alloys for Adsorption and Storage of Tritium in Thorium Based Molten Salt Reactor. Ph.D. Thesis, Graduate School of Chinese Academy of Sciences (Shanghai Institute of Applied Physics), Shanghai, China, 2016.

46. Chattaraj, D.; Parida, S.C.; Dash, S.; Majumder, C. Structural, electronic and thermodynamic properties of $\mathrm{ZrCo}$ and $\mathrm{ZrCoH}_{3}$ : A first-principles study. Int. J. Hydrogen Energy 2012, 37, 18952-18958. [CrossRef]

47. Jat, R.A.; Singh, R.; Parida, S.C.; Das, A.; Agarwal, R.; Mukerjee, S.K.; Ramakumar, K.L. Structural and hydrogen isotope storage properties of Zr-Co-Fe alloy. Int. J. Hydrogen Energy 2015, 40, 5135-5143. [CrossRef]

48. Guo, Y.; Liu, W.; Han, X.; Han, H.; Yuan, Q.; Zeng, Y.; Wu, X.; Jie, Q.; Yin, H.; Wei, L. Effects of alloying substitutions on the anti-disproportionation behavior of $\mathrm{ZrCo}$ alloy. Int. J. Hydrogen Energy 2017, 42, 15782-15789.

49. Guo, X.; Wang, S.; Liu, X.; Li, Z.; Ye, J.; Yuan, H.; Jiang, L. Structural characteristics and mechanism of hydrogen-induced disproportionation of the ZrCo alloy. Int. J. Miner. Metall. Mater. 2012, 19, 1010-1015. [CrossRef]

50. Hara, M.; Hayakawa, R.; Kaneko, Y.; Watanabe, K. Hydrogen-induced disproportionation of $\mathrm{Zr}_{2} \mathrm{M}$ ( $\mathrm{M}=\mathrm{Fe}$, $\mathrm{Co}, \mathrm{Ni}$ ) and reproportionation. J. Alloy Compd. 2003, 352, 218-225. [CrossRef]

51. Kou, H.; He, H.; Luo, W.; Tang, T.; Huang, Z.; Sang, G.; Zhang, G.; Wang, H.; Shi, Y.; Chen, C. Stable region of ZrCo under hydrogen atmosphere at high temperature. Int. J. Hydrogen Energy 2018, 43, 322-328. [CrossRef]

52. Yao, Z.; Xiao, X.; Liang, Z.; Huang, X.; Kou, H.; Luo, W.; Chen, C.; Chen, L. An in-depth study on the thermodynamics and kinetics of disproportionation behavior in $\mathrm{ZrCo}-\mathrm{H}$ systems. J. Mater. Chem. A 2020, 8, 9322-9330. [CrossRef]

53. Konishi, S.; Nagasaki, T.; Okuno, K. Reversible disproportionation of ZrCo under high temperature and hydrogen pressure. J. Nucl. Mater. 1995, 223, 294-299. [CrossRef]

54. Shim, M.; Chung, H.; Cho, S.; Yoshida, H. Disproportionation Characteristics of a Zirconium-Cobalt Hydride Bed under ITER Operating Conditions. Fusion Sci. Technol. 2008, 53, 830-840. [CrossRef]

55. Westlake, D.G. Stoichiometries and interstitial site occupation in the hydrides of zrni and other isostructural intermetallic compounds. J. Less Common Met. 1980, 75, 177-185. [CrossRef]

56. Jacob, I.; Bloch, J.M. Interstitial site occupation of hydrogen atoms in intermetallic hydrides: $\mathrm{ZrNiHx}$ case. Solid State Commun. 1982, 42, 541-545. [CrossRef]

57. Yang, S.; Aubertin, F.; Rehbein, P.; Gonser, U. A Mössbauer spectroscopy study of the system ZrNi-H and ZrCo-H. Z. Krist. Cryst. Mater. 1991, 195, 281. [CrossRef]

58. Jat, R.A.; Singh, R.; Parida, S.C.; Das, A.; Agarwal, R.; Ramakumar, K.L. Determination of deuterium site occupancy in $\mathrm{ZrCoD}_{3}$ and its role in improved durability of $\mathrm{Zr}-\mathrm{Co}-\mathrm{Ni}$ deuterides against disproportionation. Int. J. Hydrogen Energy 2014, 39, 15665-15669. [CrossRef]

59. Bekris, N.; Sirch, M. On the Mechanism of the Disproportionation of ZrCo Hydrides. Clin. Chem. 2006, 62, 50-55. [CrossRef]

60. Yang, G.; Liu, W.; Tan, J.; Wu, S.; Qiu, J.; Cheng, H.; Yin, H.; Qian, N.; Huang, Y.; Wu, X.; et al. Theoretical study of $\mathrm{ZrCoH}_{3}$ and the anti-disproportionation ability of alloying elements. Int. J. Hydrogen Energy 2018, 43, 10410-10419. [CrossRef]

61. Tan, G.L.; Liu, X.P.; Jiang, L.J.; Wang, S.M.; Li, Z.N.; Li, H.L. Dehydrogenation Characteristic of $\mathrm{Zr}_{1-\mathrm{x}} \mathrm{M}_{\mathrm{x}} \mathrm{Co}(\mathrm{M}=\mathrm{Hf}, \mathrm{Sc})$ Alloy. Trans. Nonferr. Met. Soc. China 2007, 17, s949-s953.

62. Peng, L.; Jiang, C.; Xu, Q.; Wu, X. Hydrogen-induced disproportionation characteristics of $\mathrm{Zr}(1-\mathrm{x}) \mathrm{Hf}(\mathrm{x}) \mathrm{Co}(\mathrm{x}=0,0.1,0.2$ and 0.3) alloys. Fusion Eng. Des. 2013, 88, 299-303. [CrossRef]

63. Weng, C.; Xiao, X.; Huang, X.; Jiang, F.; Yao, Z.; Li, S.; Ge, H.; Chen, L. Effect of Mn substitution for Co on the structural, kinetic, and thermodynamic characteristics of $\mathrm{ZrCo} 1-\mathrm{xMnx}(\mathrm{x}=0-0.1)$ alloys for tritium storage. Int. J. Hydrogen Energy 2017, 42, 28498-28506. [CrossRef]

64. Liang, Z.; Xiao, X.; Yao, Z.; Kou, H.; Luo, W.; Chen, C.; Chen, L. A new strategy for remarkably improving anti-disproportionation performance and cycling stabilities of ZrCo-based hydrogen isotope storage alloys by $\mathrm{Cu}$ substitution and controlling cutoff desorption pressure. Int. J. Hydrogen Energy 2019, 44, 28242-28251. [CrossRef] 
65. Luo, L.; Ye, X.; Zhao, C.; Zhang, G.; Kou, H.; Xiong, R.; Sang, G.; Han, T. Effects of Mo substitution on the kinetic and thermodynamic characteristics of $\mathrm{ZrCo}_{1-\mathrm{x}} \mathrm{Mo}_{\mathrm{x}}(\mathrm{x}=0-0.2)$ alloys for hydrogen storage. Int. J. Hydrogen Energy 2020, 45, 2989-2998. [CrossRef]

66. Luo, L.; Ye, X.; Zhang, G.; Kou, H.; Xiong, R.; Sang, G.; Yu, R.; Zhao, D. Enhancement of hydrogenation kinetics and thermodynamic properties of $\mathrm{ZrCo}_{1-\mathrm{x}} \mathrm{Cr}_{\mathrm{x}}(\mathrm{x}=0-0.1)$ alloys for hydrogen storage. Chin. Phys. $B$ 2020, 29, 88801. [CrossRef]

67. Luo, W.; Kou, H.; Huang, X.; Ye, R.; Bao, J.; He, H.; Tang, T.; Huang, Z.; Sang, G. Exploration and optimization of $\mathrm{ZrCo}(\mathrm{Ti})$ type film for high hydrogen density and thermal stability of the hydride. Int. J. Hydrogen Energy 2020, 45, 15530-15540. [CrossRef]

68. Jat, R.A.; Parida, S.; Agarwal, R.; Kulkarni, S. Effect of Ni content on the hydrogen storage behavior of $\mathrm{ZrCo}_{1-\mathrm{x}} \mathrm{Ni}_{\mathrm{x}}$ alloys. Int. J. Hydrogen Energy 2013, 38, 1490-1500. [CrossRef]

69. Yao, Z.; Xiao, X.; Liang, Z.; Kou, H.; Luo, W.; Chen, C.; Jiang, L.; Chen, L. Improvement on the kinetic and thermodynamic characteristics of $\mathrm{Zr}_{1-\mathrm{x}} \mathrm{Nb}_{\mathrm{x}} \mathrm{Co}(\mathrm{x}=0-0.2)$ alloys for hydrogen isotope storage and delivery. J. Alloys Compd. 2019, 784, 1062-1070. [CrossRef]

70. Tan, G.L.; Liu, X.P.; Jiang, L.J.; Wang, S.M.; Li, Z.N.; Li, H.L. Study on hydrogen storage properties of Zr-Hf-Co alloy. J. Xi'an Jiaotong Univ. 2007, 11, 1380-1383.

71. Huang, Z.; Liu, X.; Jiang, L.; Wang, S. Hydrogen storage properties of $\mathrm{Zr}_{1-\mathrm{x}} \mathrm{Ti}_{\mathrm{x}}$ Co intermetallic compound. Rare Met. 2006, 25 (Suppl. S2), 200-203. [CrossRef]

72. Zhao, Y.; Li, R.; Tang, R.; Li, B.; Yu, R.; Liu, W.; Kou, H.; Meng, J. Effect of Ti substitution on hydrogen storage properties of $\mathrm{Zr}_{1-\mathrm{x}} \mathrm{Ti}_{\mathrm{x}} \mathrm{Co}(\mathrm{x}=0,0.1,0.2,0.3)$ alloys. J. Energy Chem. 2014, 23, 9-14. [CrossRef]

73. Zhang, G.H.; Sang, G. Study on hydrogen storage properties and anti-hydrogen disproportionation effect of $\mathrm{Zr}_{1-\mathrm{x}} \mathrm{Ti}_{\mathrm{x}}$ Co alloy. Funct. Mater. 2015, 46, 93-99.

74. Luo, J.J.; Wang, S.M.; Liu, J.; Pan, C.S.; Liu, X.P.; Jiang, L.J. Effects of Ti partial substitution of Zr on hydrogen storage characteristics of $\mathrm{ZrNi}_{0.6} \mathrm{Co}_{0.4}$ alloy. Rare Met. 2013, 37, 521-525.

75. Xu, S.; Wang, F.; Tang, W.; Wang, Y.; Yu, R. Microstructure and hydrogen storage properties of $\mathrm{Zr}_{0.8} \mathrm{Ti}_{0.2} \mathrm{Co}_{1-\mathrm{x}} \mathrm{Fe}_{\mathrm{x}}(\mathrm{x}=0,0.1,0.2,0.3)$ alloys. Int. J. Hydrogen Energy 2018, 43, 839-847. [CrossRef]

76. Jat, R.A.; Parida, S.C.; Agarwal, R.; Ramakumar, K.L. Investigation of hydrogen isotope effect on storage properties of Zr-Co-Ni alloys. Int. J. Hydrogen Energy 2014, 39, 14868-14873. [CrossRef]

77. Jing, W.; Li, R.; Feng, W.; Ding, C.; Yu, R.; Ying, W. Effect of Ni substitution on hydrogen storage properties of $\mathrm{Zr}_{0.8} \mathrm{Ti}_{0.2} \mathrm{Co}_{1-\mathrm{x}} \mathrm{Ni}_{\mathrm{x}}(\mathrm{x}=0,0.1,0.2,0.3)$ alloys. Int. J. Hydrogen Energy 2016, 41, 7408-7418.

78. Bekris, N.; Besserer, U.; Sirch, M.; Penzhorn, R.D. On the thermal stability of the zirconium/cobalt-hydrogen system. Fusion Eng. Des. 2000, 49-50, 781-789. [CrossRef]

79. Chattaraj, D.; Parida, S.C.; Dash, S.; Majumder, C. Density functional study of vibrational, thermodynamic and elastic properties of $\mathrm{ZrCo}$ and $\mathrm{ZrCoX}_{3}(\mathrm{X}=\mathrm{H}, \mathrm{D}$ and T) compounds. J. Alloys Compd. 2015, 629, 297-304. [CrossRef]

80. Zhang, P.; Wang, B.-T.; He, C.-H.; Zhang, P. First-principles study of ground state properties of $\mathrm{ZrH}_{2}$. Comput. Mater. Sci. 2011, 50, 3297-3302. [CrossRef]

81. Chattaraj, D.; Parida, S.C.; Dash, S.; Majumder, C. First principles study of the $\mathrm{ZrX}_{2}(X=H, D$ and T) compounds. Int. J. Hydrogen Energy 2014, 39, 9681-9689. [CrossRef]

82. Kanagaprabha, S.; Asvinimeenaatci, A.T.; Sudhapriyanga, G.; Jemmycinthia, A.; Rajeswarapalanichamy, R.; Iyakutti, K.J.A.P.P. First Principles Study of Stability and Electronic Structure of $\mathrm{TMH}$ and $\mathrm{TMH}_{2}(\mathrm{TM}=\mathrm{Y}, \mathrm{Zr}$, $\mathrm{Nb}$ ). Acta Phys. Pol. A 2012, 123, 126-131. [CrossRef]

83. Zhang, P.; Wang, S.; Zhao, J.; He, C.; Zhao, Y.; Zhang, P. First-principles study of atomic hydrogen adsorption and initial hydrogenation of $\operatorname{Zr}(0001)$ surface. J. Appl. Phys. 2013, 113, 013706. [CrossRef]

84. Gupta, M. Electronic structure and stability of hydrides of intermetallic compounds. J. Alloys Compd. 1999, 293-295, 190-201. [CrossRef]

85. Chattaraj, D.; Kumar, N.; Ghosh, P.; Majumder, C.; Dash, S. Adsorption, dissociation and diffusion of hydrogen on the $\mathrm{ZrCo}$ surface and subsurface: A comprehensive study using first principles approach. Appl. Surf. Sci. 2017, 422, 394-405. [CrossRef]

86. Hohenberg, P.; Kohn, W. Inhomogeneous Electron Gas. Phys. Rev. 1964, 136, B864-B871. [CrossRef]

87. Kohn, W.; Sham, L.J. Self-Consistent Equations Including Exchange and Correlation Effects. Phys. Rev. 1965, 140, A1133-A1138. [CrossRef] 
88. Kresse, G.; Furthmüller, J. Efficient iterative schemes for ab initio total-energy calculations using a plane-wave basis set. Phys. Rev. B 1996, 54, 11169-11186. [CrossRef] [PubMed]

89. Blöchl, P.E. Projector augmented-wave method. Phys. Rev. B 1994, 50, 17953-17979. [CrossRef]

90. Perdew, J.P.; Chevary, J.A.; Vosko, S.H.; Jackson, K.A.; Pederson, M.R.; Singh, D.J.; Fiolhais, C. Atoms, molecules, solids, and surfaces: Applications of the generalized gradient approximation for exchange and correlation. Phys. Rev. B 1992, 46, 6671-6687. [CrossRef]

91. Henkelman, G.; Uberuaga, B.P.; Jónsson, H. A climbing image nudged elastic band method for finding saddle points and minimum energy paths. J. Chem. Phys. 2000, 113, 9901-9904. [CrossRef]

92. Henkelman, G.; Jónsson, H. Improved tangent estimate in the nudged elastic band method for finding minimum energy paths and saddle points. J. Chem. Phys. 2000, 113, 9978-9985. [CrossRef]

93. Jat, R.A.; Parida, S.C.; Nuwad, J.; Agarwal, R.; Kulkarni, S.G. Hydrogen sorption-desorption studies on ZrCo-hydrogen system. J. Therm. Anal. Calorim. 2013, 112, 37-43. [CrossRef]

94. Henkelman, G.; Arnaldsson, A.; Jónsson, H. A fast and robust algorithm for Bader decomposition of charge density. Comput. Mater. Sci. 2006, 36, 354-360. [CrossRef]

95. You, Y.-W.; Yu, J.; Yuan, H.; Xu, Y.; Wu, X.; Sun, J.; Wang, J.; Fang, Q.F.; Liu, C.S. Systematical study on the roles of transition alloying substitutions on anti-disproportionation reaction of $\mathrm{ZrCo}$ during charging and releasing hydrogen. Int. J. Hydrogen Energy 2020, 45, 14028-14037. [CrossRef]

96. Jat, R.A.; Singh, R.; Pati, S.; Sastry, P.U.; Das, A.; Agarwal, R.; Parida, S.C. An analogy of interstitial site occupancy and hydrogen induced disproportionation of $\mathrm{Zr}_{1-\mathrm{x}} \mathrm{Ti}_{\mathrm{x}}$ Co ternary alloys. Int. J. Hydrogen Energy 2017, 42, 8089-8097. [CrossRef]

97. Guo, X.; Wang, S.; Li, Z.; Yuan, B.; Ye, J.; Qiu, H.; Wu, Y.; Liu, X.; Jiang, L. Study on the poisoning resistance of Pd-coated ZrCo alloy prepared by electroless plating method. Fusion Eng. Des. 2016, 113, 195-200. [CrossRef]

98. Wang, F.; Li, R.; Ding, C.; Tang, W.; Wang, Y.; Xu, S.; Yu, R.; Wang, Z. Effect of catalytic Pd coating on the hydrogen storage performances of $\mathrm{ZrCo}$ alloy by electroless plating method. Int. J. Hydrogen Energy 2017, 42, 11510-11522. [CrossRef]

99. Gleiter, H. Advanced Structural and Functional Materials. In Nanocrystalline Materials; Bunk, W.G.J., Ed.; Springer: Berlin/Heidelberg, Germany, 1991; pp. 1-37.

100. Zaluski, L.; Zaluska, A.; Ström-Olsen, J.O. Nanocrystalline metal hydrides. J. Alloys Compd. 1997, 253-254, 70-79. [CrossRef]

101. Orimo, S.; Fujii, H. Effects of nanometer-scale structure on hydriding properties of Mg-Ni alloys: A review. Intermetallics 1998, 6, 185-192. [CrossRef]

102. Fichtner, M. Properties of nanoscale metal hydrides. Nanotechnology 2009, 20, 204009. [CrossRef]

103. Huot, J. Nanocrystalline Metal Hydrides Obtained by Severe Plastic Deformations. Metals 2012, 2, $22-40$. [CrossRef]

104. Zhu, M.; Lu, Y.; Ouyang, L.; Wang, H. Thermodynamic Tuning of Mg-Based Hydrogen Storage Alloys: A Review. Materials 2013, 6, 4654-4674. [CrossRef]

105. Kou, H.; He, H.; Luo, W.; Tang, T.; Huang, Z.; Wang, H.; Bao, J.; Xue, Y.; Pei, S.; Liu, W. Effects of ball milling on hydrogen sorption properties and microstructure of ZrCo alloy. Fusion Eng. Des. 2019, 138, 68-77. [CrossRef]

106. Qi, Y.; Ju, X.; Wan, C.; Qiu, J.; Xin, Y.; Wang, S.; Liu, X.; Jiang, L. EXAFS and SAXS studies of ZrCo alloy doped with Hf, Sc and Ti atoms. Int. J. Hydrogen Energy 2010, 35, 2931-2935. [CrossRef]

107. Wang, F.; Li, R.; Ding, C.; Wan, J.; Yu, R.; Wang, Z. Effect of catalytic Ni coating with different depositing time on the hydrogen storage properties of ZrCo alloy. Int. J. Hydrogen Energy 2016, 41, 17421-17432. [CrossRef]

(C) 2020 by the authors. Licensee MDPI, Basel, Switzerland. This article is an open access article distributed under the terms and conditions of the Creative Commons Attribution (CC BY) license (http://creativecommons.org/licenses/by/4.0/). 